was more simple than the Gregorian, and that there was no object in keeping the date of the month and day of any year corresponding exactly to the season in years several centuries apart ; and no doubt Julius Cæesar was aware that the tropical year (as we call that on which the seasons depend) was several minutes short of three hundred and sixty-five days and a quarter in length. No doubt also the omission of several days on the greatest part of the continent in the sixteenth century, and in England in the middle of the eighteenth century, owing to the supposed necessity of making the seasonal dates correspond to what they were at the epoch of the Council of Nicrea, must have caused much confusion. But all that has long been a thing of the past; and it would seem best now to have, if possible, a general usage keeping the year in accordance with its true length.

W. T. LYNN.

\section{THE MELBOURNE MEETING OF THE AUSTRALASIAN ASSOCIATION.}

THE eighth annual meeting of the Australasian Association for the Advancement of Science was opened in Melbourne on January 9, in the University buildings, which were placed at the disposal of the Association. At the inaugural meeting, the President of the last session, Prof. Liversidge, F.R.S., vacated the chair in favour of the President-elect, $\mathrm{Mr}$. R. L. J. Ellery, C.M.G., F.R.S., the late Government Astronomer of Victoria, who delivered an address on " The beginnings and growth of astronomy in Australia," in which he sketched the progress of astronomical science from the days of Captain Cook up to the foundation of well-equipped observatories in Melbourne, Sydney, Adelaide, and, more recently, in Perth, concluding with a reference to the co-operation, at the present time, of the three first observatories in the international survey of the heavens by means of photography, for the purpose of forming a chart of all stars down to the fourteenth magnitude.

The following Presidential addresses were delivered in the various sections: Astronomy, Mathematics and Physics, by Mr. G. H. Knibbs, on "The development of the atomic theory of matter"; Chemistry, by Mr. F. B. Guthrie, on "Some landmarks in the progress of chemical science"; Geology, by Prof. R. Tate, on "An attempt at a refutation of the doctrine of homotaxy"; Biology, by Mr. J. J. Fletcher, on "The rise and early progress of our knowledge of the Australian fauna"; Geography, by Mr. W. H. Tietkins, on "A review of geographical research during the past two years"; Ethnology, by Mr. F. J. Gillen, on "Magic amongst the Central Australian natives"; Economic Science, by Prof. Jethro Brown, on "Loyalty, liberty, brotherhood: a study in the political ideal"; Agriculture, by Prof. Lowrie, "That in our practice of agriculture the determining influence of climatic conditions is not sufficiently recognised"; Engineering, by Mr. H. Deane, on "The George Street tramway, Sydney"; Sanitary Science, by Dr. Jamieson, on "The advance of sanitary science"; Mental Science, by Dr. Cleland, on "The anatomy of mind as bearing upon education." In the various sections 160 papers were read. Public lectures were delivered by Prof. Morris, on "Early men of science in Australia "; by Dr. George Brown, on "An anthropologist in the South Seas"; and by Mr. H. W. Jenvey (to working men), on "The Marconi system of wireless telegraphy."

Reports were received upon the magnetic survey of New Zealand, and also from the seismological committee, the photographic geological survey committee, and the glacial committee. Amongst others, committees were formed to investigate and report upon the is. I 5 \&6. VOL. $6 \mathrm{I}]$ following subjects : the best method of utilising diamond drill bores for the determination of underground temperatures; the drawing up of a catalogue of recent Australian and Tasmanian marine shells; the collecting and cataloguing of geological photographs of interest in Australia and Tasmania; the need of separate State education for defective children. It was determined to urge the various Colonial Governments to adopt a uniform system of spelling native names of places in accordance with that adopted by the Admiralty and the Royal Geographical Society, and to approach the Governments of the several colonies with the object of trying to induce them to provide for the appointment of a properly qualified philological expert to make researches into the Australian and Papuan languages.

It was decided to hold the next session in Hobart, in January 1902, Captain Hutton being nominated as President. Prof. Liversidge was reappointed Permanent Secretary, and Mr. H. C. Russell, Treasurer. The arrangements for the meeting was made by Prof. Baldwin Spencer, the organising secretary for Victoria.

An instructive "Handbook of Melbourne," edited by Prof. Baldwin Spencer, was published for the use of members of the Association. Mr. A. Sutherland contributes the opening chapter, on the history of Victoria, and he concludes it with the following remarks, which show that there has always been enthusiasm for scientific work in the colony. "When the colony was but a couple of years old, a mechanics' institute was formed with its courses of scientific lectures and its little museum. A botanic garden was laid out when Melbourne was three years old, and when the goldfields had brought to its shores crowds of energetic and intelligent men, the fervour for knowledge increased. A National Museum, a University, a great Public Library, on a plan to cost eventually a million of money, and to form a vast national repository of all that science, literature and art could provide, were the notable features of that period; but amongst them must also be reckoned the Royal Society, the result of the amalgamation of two rival efforts in the cause of science. The Society has completed some forty years of existence, with a volume of papers for nearly every year."

The geology, biology in its various branches, ethnology, climate, commerce and manufactures of the colony form the subject of different chapters in the volume, and much valuable information is given in a concise form.

\section{THE BI-CENTENARY OF THE BERLIN $A C A D E M Y$.}

AST week we referred to the history of the Berlin Academy during the present century. The celebration of the bi-centenary was commenced on Monday. From the telegraphic account which appears in the Times, we gather that the Emperor opened the celebration by receiving in state the members of the Academy as well as the foreign deputations which have come to Berlin. The reception took place in the White Hall of the Royal Castle in the presence of the German Crown Prince, many princes of the Prussian and other German Royal Houses, the foreign Ambassadors, the Imperial Chancellor, and the Ministers and Secretaries of State. His Majesty, who wore the white uniform of the Gardes du Corps, with the eagle-crested helmet, sat on the throne surrounded by the insignia of Empire, the crown, sceptre, sword, orb and seal, which had been brought in on cushions of gold and silver cloth by the Minister of War and other generals. On a table near the throne were a pile of books, globes, and scientific instruments "picturesquely arranged" and surmounted by an eagle carrying a twig of laurel. Before the pro- 
ceedings were opened by the dutiful addresses of the secretary of the Academy (Prof. Auwers), and the Minister of Education (Dr. Studt), a choir from the Royal School of Music sang Haydn's "Du bist dem Ruhm und Ehre gebiihrt." At the close of the ceremony, Löwe's "Salvum fac Regem " was sung.

In the speech from the throne his Majesty welcomed the delegates and recalled the long and intimate connection which had existed between the Academy and the House of Hohenzollern, and its foundation by the Elector Frederick III. (King Frederick I. of Prussia) on the initiative of Leibnitz, its first president. Al the Prussian kings had been protectors of the society. William I. had said :- "The interest in learning which is felt by every Prussian king is shared by me." These words had been illus trated in connection with the Academy. The Emperor was glad to be able to say that the society had now maintained its activity throughout two centuries, and had completely fulfilled the expectations which his ancestors had placed in it. There were, no doubt, good reasons for the fact that German science had developed in close connection with the Universities. As the immortal Helmholtz had borne witness, academic teaching and intercourse with the students furnished abundant sources of energy for scientific research. But none the less the organisation and conduct of scientific work by academies had proved itself to be an essential element of scientific progress, and one which could not he neglected if great objects were to be attained. The Academy had come into existence more than a century before the University of Berlin, and had at an earlier date undertaken the task of simultaneously promoting all branches of learning. The Emperor intimated that he would now extend the society by the addition to the philosophical and historical section of a number of chairs principally devoted to German philological research. German philological research, his Majesty considered, should be especially cultivated in the capital of the United German Empire. The physical and mathematical section was to be strengthened in the same way, in consideration of the importance of the technical sciences in the presênt day.

"The Academy," continued the Emperor, "has trom the very beginning taken all knowledge to be its province, but, on the other hand, it can be said to its credit that it has refrained from the pursuit of every interest unconnected with learning. The great events of the national life have, indeed, been reflected in its activity, and have often found enthusiastic expression in the words of its speakers on festal occasions. But the Academy has always disdained to descend into the turmoil of political passions, and has regarded the pure and disinterested cultivation of science as its highest duty. In this unselfish devotion, to which it owes so much, and which is a guarantee for its further success, the Academy serves the divinely appointed object of all knowledge, which is to lead mankind 10 a more profound understanding of Divine truth. However, the natural sciences may seek as their final goal to discover the first cause of all being and phenomena, it still remains true that, in the words of Goethe, himself once a foreign member of this society, "the real, the only, and the profoundest theme of the history of the world and of humanity, a theme to which all others are subordinate, is the conflict between belief and unbelief,' and-as should be added, in conformity with his meaning-the dealings of God with man. So it holds good of your work that, as was the desire of Liebnitz, "the honour of God and the good of all humanity are constantly promoted' by science. May this always be so, and to that end may the blessing of the Most High rest upon you in the new century as in the past."

In connection with the bi-centenary the Emperor has conferred the Order of the Red Eagle, first-class, upon Prof. Mommsen; the star of the Royal Order of the Crown, second-class, upon Prof. Auwers, the permanent secretary of the Academy; the Order of the Red Eagle, third-class, upon Prof. Adolf Karnack; and a number of distinctions upon other eminent scholars and men of science who have rendered services to the Academy.

Lord Kelvin and Prof. Max Müller have been elected Foreign Members. The following Englishmen and Ame:icans have been elected Corresponding Members :-Prof. Gibbs, of Newhaven Prof. Rowland, of Baltimore ; Sir J. Burdon-Sanderson, Bart., of Oxford ; Prof. William James, of Cambridge, Mass. ; Prof. Kenyon, of London; Prof. Mahaffy, of Dublin; Dr. A. S. Murray, of the British Museum ; Mr. F. L. Griffith, of Ashton. under-Lyne; and Prof. F. W. Maitland, of Cambridge.

NO. I 586 , VOL. 6 I]
A special meeting of the Academy was held on Tuesday in the Prussian Chamber of Deputies, in celebration of the bicentenary. Among those present were the Imperial Chancellor (Prince Hohenlohe), the Italian Ambassador (Count Lanza), the British Ambassador (Sir Frank Lascelles), and the Ambassador of Austria-Hungary (Herr von Szögyeny-Marich). The proceedings were opened and closed by wonderful performances of an orchestra from the Royal School of Music under Prof. Joachim, which played a sonata by Giovanni Gabrieli (1597) and Stadler's hymn, "Grosser Gott, Allmächtiger Gott." Prof. Harnack delivered an eloquent address on the history of the Academy, and concluded with the words:- " May the light which was in the beginning and the word which was in the beginning continue to illuminate the spirit of this institution in the third century of its existence !"

The representatives of foreign academies and learned societies then presented addresses of congratulation. The following were among the foreign deputations:-On behalf of the Royal Society of London, Dr. T. E. Thorpe and Prof. W. Ramsay; for the Royal Irish Academy, Dublin, Prof. R. Atkinson and Prof. Mahaffy ; for the Royal Society of Edinburgh, Dr. J. Burgess and Dr. R. H. Traquair; for the Royal Asiatic Society of Great Britain and Ireland, Dr. M. Gasten and Mr. H. Lyon; for the Smithsonian Institution of Washington, the Ambassador of the United States of America, Mr. Andrew D. White; for the American Academy of Arts and Sciences, Prof. J. W. White and Prof. J. C. Wolff, of Harvard University ; for the Académie des Inscriptions et Belles-Lettres de l'Institut de France, M. Gaston Paris and M. E. Senart; for the Académie des Sciences de l'Institut de France, M. G. Darboux, Doyen de la Faculté de Sciences de Paris; for the Académie des Sciences Morales et Politiques de l'Institut, M. Gréard, Rector de l'Université de Paris, and the Comte de Franqueville, Vice-Président de l'Academie. Dr. Nansen also presented congratulations.

In replying to the addresses of the deputations, Prof, Diels said that contemporaneous with the bi-centenary of the Berlin Academy was the birth of what he might call the "academy of the world," the international association of the academies of all countries, founded four weeks ago. After sketching the objects of this association, he announced that he was able to lay on the table the first fruits of its labours in the shape of the first printed sheets of the "Thesaurus Linguæ Latinæ." He expressed the hope that the nations might follow the example of the academies and the Universities by uniting in the peaceful task of extending to the whole world the civilisation and the culture of Europe and America.

\section{INNERMOST ASIA.}

DROMPTED more by the love of sport than by any scientific aspiration, Mr. Cobbold undertook an adventurous (and in many respects an instructive) journey from India into the regions of High Asia; and regarded as a record of sport and adventure, he has told his tale so well that he is likely to produce an embarrassing demand on the Indian Foreign Department for leave to follow in his footsteps. He seems to have had no special difficulty in obtaining permission to visit the Pamirs, in spite of the well known reluctance of the Indian Government to entertain the risk of "complications" involved in the casual collisions of British and Russian officers on the far frontier. Indeed, he naturally finds it difficult to understand why so many more obstacles were placed in the way of his return than of his visit to the Pamirs.

In August 1897, he followed the high road through Kashmir to Gilgit and Hunza, crossing the Kilik Pass in the company of Captain Deasy, who was bent on a scientific mission in the same direction. After fair success with Ovis poli in the neighbourhood of the Tagdumbash Pamir, he passed on to Kashgar and started northward from that place to Vierney and Lake Balkash. In the reed beds that surround Balkash he achieved a notable feat, for he bagged a tiger under circumstances that were sufficiently exciting to satisfy the most ardent sportsman ; and this may surely rank as 1 " Innermost Asia." By Ralph P. Cobbold. Pp. xviii +354 . (London: Heinemann, Igoo.) 